\title{
НОВОЧАСНИЙ СТАН I ПЕРСПЕКТИВИ ВДОСКОНАЛЕННЯ ЗАКОНОДАВЧОГО ПРОСТОРУ УКРАЇНИ В ЗАБЕЗПЕЧЕННІ ПРАВ, СВОБОД I ЗАКОННИХ ІНТЕРЕСІВ УЧАСНИКІВ КРИМІНАЛЬНОГО ПРОВАДЖЕННЯ
}

Ребезюк В. М.

У науковій статті досліджується питання вдосконалення законодавчого простору в забезпеченні прав, свобод і законних інтересів учасників кримінального провадження у світлі євроінтеграційного напрямку розвитку українського правового поля, в оптимізації кримінального законодавства.

Досліджуються шляхи вдосконалення кримінальної юстиції в нашій країні, що це складне завдання, в контексті якого повинна бути реалізована ціла програма послідовних і взаємно визначених дій. Основними векторами в напрямку процесу побудови ідеальної правової системи з погляду забезпечення прав, свобод і законних інтересів людини повинні стати такі принципи:

- засвоєння передових досягнень у сфері законодавчих технологій у провідних демократіях світу;

- відтворення у національному законодавстві передових ідей щодо посилення гарантій прав і свобод людини;

- дослідження практики міжнародних органів та організачій щодо діяльності із забезпечення прав, свобод і законних інтересів людей, зокрема Європейського суду з прав людини;

- аналіз і вивчення позитивного досвіду прецедентного права країн з англо-американською правовою системою.

Ключові слова: законодавчий простір, правові стандарти, забезпечення прав, кримінальне провадження, євроінтеграція, ефективний захист.

В научной статье исследуется вопрос усовершенствования законодательного пространства в обеспечении прав, свобод и законных интересов участников уголовного производства в свете евроинтеграционного направления развития украинского правового поля, в оптимизации уголовного законодательства.

Исследуются пути совершенствования уголовной юстиции в нашей стране, сложная задача, в контексте которой должна быть реализована челая программа последовательных и взаимно определенных действий. Основными векторами в направлении процесса построения идеальной правовой системы с точки зрения обеспечения прав, свобод и законных интересов человека должны стать следующие принципы:

- усвоение передовых достижений в области законодательных технологий в ведущих демократиях мира;

- воспроизведение в национальном законодательстве передовых идей относительно усиления гарантий прав и свобод человека;

- исследование практики международных органов и организаций о деятельности по обеспечению прав, свобод и законных интересов людей, в частности Европейского суда по правам человека;

- анализ и изучение положительного опыта прецедентного права стран с англо-американской правовой системе.

Ключевые слова: законодательное пространство, правовые стандарты, обеспечение прав, уголовное производство, евроинтеграция, эффективная защита.
The article deals with the issue of improving the legislative space in ensuring the rights, freedoms and legitimate interests of participants in criminal proceedings in the light of the eurointegration direction of development of the Ukrainian legal field, in optimization of criminal legislation. The ways of improving criminal justice, in our country, are being studied, that this is a complex and complex task, in the context of which a whole program of consistent and mutually determined actions should be implemented. The main vectors in the direction of the process of constructing an ideal legal system from the point of view of ensuring the rights, freedoms and legitimate interests of man should become the following guidelines:

- mastering of advanced achievements in the field of legislative technology in the leading democracies of the world;

- reproduction in national legislation of advanced ideas on strengthening the guarantees of human rights and freedoms;

- study of the practice of international bodies and organizations on activities to ensure the rights, freedoms and legitimate interests of people, in particular the European Court of Human Rights;

- analyzation and study of the positive experience of the case law of countries with the Anglo-American system of law. The process of developing and introducing an effective legal mechanism for protecting the rights of individuals in the field of criminal proceedings is based on the constitutional principles of our state and international pariah acts on these issues. The procedural procedure for criminal proceedings is carried out only by the criminal procedural law, which should not contradict the provisions of the Constitution of Ukraine, international treaties, the consent to be bound by which is provided by the Verkhovna Rada of Ukraine.

At the same time, the current integration processes require appropriate improvement and rethinking of many legal institutes of criminal proceedings, which is caused by a conceptually new approach and practice of applying the latest CPC of Ukraine.

The proper provision and realization of the rights and the legitimate interests of each person is a decisive component of the formation and development of the rule of law, its main and ultimate goal. The right to protect any person who needs it is provided by the state, its competent legislative, administrative and judicial bodies.

Key words: legislative space, legal standards, rights protection, criminal proceedings, eurointegration, effective protection.

Постановка проблеми та її актуальність. Виносячи на розсуд цілком нагальне і актуальне питання, а що ж обумовлює необхідність проведення вдосконалення національного законодавства у забезпеченні прав, свобод та законних інтересів учасників кримінального провадження?

Можемо без помилково констатувати - це євроінтеграційний курс нашої держави, саме у рамках глобаль- 
ного підвищення правових стандартів забезпеченості гуманістичного початку в усіх сферах нашого суспільства, а кримінальне судочинство являє собою об'єкт особливої уваги світової спільноти. Визнання та повага даних стандартів, загальновизнаних принципів у галузі забезпечення прав людини та відповідних норм міжнародних документів, їхнє приведення у відповідність 3 національним законодавством $€$ тією необхідною умовою повноправного членства України у міжнародному співтоваристві. Запорукою успішної побудови правової держави на основі формування якісної системи процесуальних гарантій, стане ефективне забезпечення прав, свобод та законних інтересів людини у галузі кримінального провадження. «Утвердження і забезпечення прав і свобод людини і громадянина $\epsilon$ головним обов'язком держави», - зазначається у ч. 2 ст. 3 Конституції України [1, с. 5].

Метою статті $\epsilon$ дослідження та аналіз шляхів вдосконалення кримінального судочинства, в нашій державі, що це $\epsilon$ складна та комплексна задача, у контексті розв'язання якої має бути реалізована ціла програма послідовних та взаємообумовлених дій.

Основними векторами в напрямку започаткованого процесу побудови ідеальної правової системи з точки зору забезпеченості прав, свобод і законних інтересів людини повинні стати такі орієнтири:

перейняття передових досягнень у галузі законодавчої техніки в передових демократичних країнах світу; відтворення у національному законодавстві передових ідей щодо посилення гарантій прав та свобод людини;

дослідження практики міжнародних органів та організацій щодо діяльності із забезпечення прав, свобод та законних інтересів людини, зокрема Європейського суду з прав людини;

аналіз та дослідження позитивного досвіду прецедентного права країн з англо-американською системою права.

Виклад основного матеріалу. Сьогодні в Україні стан справ у сфері забезпечення охорони прав, свобод та законних інтересів учасників кримінального провадження, їхня практична реалізація $€$ тим наріжним каменем розвитку будь-якої сучасної країни, зокрема України та її суспільства загалом.

У нашій державі немає загальновизнаного європейського підходу до розуміння принципу «rule of law», який в україномовному варіанті отримав назву «верховенство права», в Україні цей принцип тільки декларується. Досить звернутися до статистики, так за даними міжнародної неурядової організації «World Justische Projekt» у рейтингу верховенства права Україна за 2018 рік посіла 77-е місце із 126 країн світу. Порівняно з попередніми оцінками наша держава піднялася на чотири позиції та $є$ сьомою з 13 країн Східноєвропейського регіону та Центральної Азії [9].

Індекс верховенства права відображає забезпечення законності в тій чи іншій країні. Можна констатувати, що нині в Україні досить значні проблеми з вирішенням законності та самим верховенством права.

За своєю суттю сама по собі доктрина правової держави припускає в собі об'єктивні передумови для формування та аналізу характерного права особи - це ефективний захист ії прав, свобод і законних інтересів. Тож логічність даного питання полягає у тому, що в подальшому посилення права особи на захист від кримінального переслідування, як одного з базових прав людини, слугуватиме розбудові та укріпленню правової демократичної держави в якій би кожна особа могла почувати себе захищеною від беззаконня і несправедливості

На думку О.Ф. Скакун, демократія в будь-якому суспільстві тримається на двох головних засадах - це верховенство закону i забезпечення прав людини. Однак навіть гуманне проголошення людини найвищою соціальною цінністю та закріплення в конституції іiі основних прав і свобод не може мати жодного значення без реальних гарантій здійснення цих прав [6, с. 202].

В Основному Законі України в положеннях ст. ст. 3, 21, 22, 55 чітко закріплено, що держава не лише визнає основні права i свободи людини, але i те, що права і свободи та їх гарантії визначають зміст і спрямованість діяльності держави, що права і свободи людини не $\epsilon$ вичерпними і що вони не можуть бути звуженні у своєму обсягу.

І відповідно до ч. 1 ст. 55 Конституції України права і свободи людини і громадянина захищаються судом. А розд. 8 ч. 3 Конституції України гарантує звернення до суду для захисту конституційних прав і свобод людини і громадянина безпосередньо на підставі тієі ж Конституції, оскільки норми Конституції $€$ нормами прямої дії [1, с. 5-9].

А також у ч. 1 та 2 ст. 24 Конституції України зафіксовано, що громадяни мають рівні конституційні права і свободи та $є$ рівними перед законом, а у ст. 129 їі визначено рівність всіх учасників судового процесу перед законом і судом. Це положення також закріплено у п. 3 ст. 7 КПК України «Загальні засади кримінального провадження» [2, с. 7-8]. Це положення Конституції підтверджується цілим рядом міжнародними правовими актами, які парафувала наша держава.

Адаптаційні процеси в європейському напрямку України знайшли своє відображення і у новітньому законодавстві, що також $\epsilon$ джерелом кримінального процесуального права України, а саме - у законах України «Про безоплатну правову допомогу» від 02.06.2011 р., «Про забезпечення права на справедливий суд» від 12.02.2015 р., «Про прокуратуру» від 14.10.2014 р., «Про Національне антикорупційне бюро України» від 14.10.2014 р., «Про державне бюро розслідувань» від 12.11.2015 р., «Про Національну поліцію» від 02.07.2015 р., «Про пробацію» від 05.02.2015 р.

У Преамбулі Статуту ООН в ст. 7 про охорону прав зазначено таке: «Всі люди рівні перед законом і мають право, без будь-якої різниці, на рівний їх захист законом. Усі люди мають право на рівний захист від якої б то не було дискримінації, що порушує цю Декларацію, і від якого б то не було підбурювання до такої дискримінації» [16, с. 824].

Ба більше, наприклад, ст. 59 Конституції України проголошує право кожного на правову допомогу та вільний вибір захисника своїх прав, а відповідно до ст. 63 закріплюється право на захист підозрюваного, обвинуваченого чи підсудного. Відповідно до ст. 7 КПК України забезпечення права на захист віднесено до загальних засад кримінального провадження. Питання дотримання права на захист у кримінальному провадженні $\epsilon$ актуальним для всіх його стадій, оскільки вимагає забезпечення підозрюваного, обвинуваченого, 
засудженого захисником, який зобов'язаний добросовісно виконувати свої професійні обов'язки та недопущення випадків обмеження у праві на захист. Під час досудового розслідування мають місце порушення права на вільний вибір захисника. Нерідко за наявності у підозрюваного захисника за угодою без повідомлення його про необхідність участі у проведенні тих чи інших процесуальних дій слідчим залучається захисник за призначенням.

Процес вироблення та запровадження дієвого правового механізму захисту прав особи у сфері кримінального провадження базується на конституційних засадах нашої держави та міжнародних парових актах з даних питань. Процесуальний порядок кримінального провадження здійснюється лише кримінальним процесуальним законодавством, яке не повинно суперечити положенням Конституції України, міжнародним договорам, згода на обов'язковість яких надана Верховною Радою України.

Отже, нинішні інтеграційні процеси вимагають відповідного вдосконалення та переосмислення багатьох правових інститутів кримінального провадження, що викликано концептуально новим підходом і практикою застосування новел чинного КПК України.

На думку О.П. Герасимчука, поняття «захист» вживається у кримінальному процесі у різних значеннях: у вузькому - як функція, що здійснюється стороною, яка повністю чи частково спростовує пред'явлене обвинувачення, підозру у вчиненні кримінального правопорушення, доводить меншу ступінь вини або ж загалом заперечує кримінальне переслідування (наприклад «сторона захисту» - сторона, яка здійснює таку діяльність) і в широкому - як охорона прав, свобод та законних інтересів учасників кримінального судочинства. На думку вченого, яку ми підтримуємо, згаданий термін у широкому значенні повною мірою може бути вжитий щодо потерпілого. У цьому разі захист потерпілого відбувається від порушень, які вже мали місце, і стали наслідком кримінального правопорушення, що настав, та від порушень прав (реальних та потенціальних), що вчиняються (або ж можуть вчинятись) в процесі відновлення справедливості [4, с. 1-2].

У зв'язку з цим В.Т. Маляренком, який, аналізуючи досвід іноземних країн, що пройшли фазу сприйняття прав і свобод окремої людини як категорії, що превалює над інтересами суспільства, дійшов висновку, що розширення прав кожного із учасників процесу повинно здійснюватися у розумних межах [5, с. 388].

Аналізуючи стратегічний напрямок подальшого реформування кримінального процесуального законодавства України з метою адаптації його до Acquis $€ C$ у секторі кримінальної юстиції, сучасного правового регулювання порядку здійснення кримінального провадження, правозастосовної практики органів досудового розслідування та суду, слід згадати поро нещодавно прийнятий Закону України №8490 від 18.09.2018 р. «Про внесення змін до деяких законодавчих актів України щодо удосконалення забезпечення дотримання прав учасників кримінального провадження та інших осіб правоохоронними органами під час здійснення досудового розслідування».

Прийняті новели в даному законі можна розділити на дві групи, перші, що стосуються розширення процесуальних прав деяких учасників кримінального прова- дження, і другі - це ті, що стосуються відшкодування завданої неправомірними діями правоохоронців шкоди. Зокрема, передбачається можливість звертатися до слідчого судді з клопотанням про закриття кримінального провадження, якщо закінчилися встановлені в ч. 1 ст. 219 КПК України строки досудового розслідування з моменту внесення відомостей про кримінальне правопорушення до ЄРДР до дня повідомлення особі про підозру.

Де було внесено зміни до ст. ст. 220, 284, 303, 309 КПК, в частині надання права учасникам кримінального провадження заявляти клопотання слідчому, прокурору про закриття кримінального провадження, якщо існує не скасована постанова слідчого, прокурора про закриття кримінального провадження у разі встановлення відсутності події кримінального правопорушення, відсутності в діянні складу кримінального правопорушення.

Запропоновані зміни забезпечать можливість учасникам кримінального провадження, у тому числі іншим особам, права чи законні інтереси яких обмежуються під час досудового розслідування, подавати клопотання про закриття кримінального провадження із зазначених вище підстав, яке слідчий, прокурор буде зобов'язаний розглянути в строк не більше трьох днів з моменту подання і задовольнити за наявності відповідних підстав, а у разі відмови оскаржити таке рішення до суду.

Щодо новел, які стосуються відповідальності слідчих та прокурорів за завдану шкоду, то відтепер, окрім виправдувального вироку суду; рішення суду, яким встановлено незаконність процесуальних дій, що обмежують чи порушують права та свободи громадян, та рішення про закриття кримінального провадження, підставою для відшкодування шкоди, завданої правоохоронними органами, може бути також ухвала слідчого судді про задоволення скарги на рішення, дії чи бездіяльність слідчого або прокурора.

Держава також отримала механізм стягнення безпосередньо з винних службових осіб правоохоронних органів коштів, виплачених в якості компенсації за завдану ними шкоду. Проте $\epsilon$ обґрунтований ризик, що такі зміни виявляться не дієвими, оскільки у слідчого судді за результатами розгляду скарги на рішення, дію чи бездіяльність слідчого або прокурора відсутні повноваження визнати такі діяння незаконними або такими, що порушують права осіб. Це унеможливлює притягнення прокурорів до дисциплінарної відповідальності, оскільки Закон України «Про прокуратуру» прямо встановлює, що підставою для дисциплінарного провадження $\epsilon$ встановлення судом зазначених вище фактів. У цьому разі, на нашу думку, логічним виглядало б доповнення ч. 2 ст. 307 КПК України додатковим пунктом, який би надавав слідчим суддям повноваження за результатами розгляду відповідних скарг не лише скасовувати рішення чи зобов'язувати вчинити певні дії, але і встановлювати факти порушення слідчим чи прокурором прав осіб або вимог закону.

Це слугуватиме кращому захисту прав та інтересів осіб, інтереси яких обмежуються під час досудового розслідування, що спрощуватиме діяльність правників, які надають допомогу таким людям. Слідчий чи прокурор будуть відповідати і компенсувати шкоду, завдану кримінальними правопорушеннями, тобто діями, передбаченими Кримінальним Кодексом України, 
а також шкоду, завдану дисциплінарними проступками, тобто порушенням вимог нормативних актів, що встановлюють обов'язки співробітників правоохоронних органів,

На думку Г.Й. Удовенко, права людини мають бути тим мірилом розвитку демократії, до якої ми так прагнемо. Права людини це компас, за яким держава повинна звіряти свою діяльність в усіх сферах суспільного життя [8, с. 8].

Зі свого боку, Д.Е. Аблязов зазначав, що проблема належного забезпечення прав людини і громадянина в наш час $\epsilon$ складною як у теоретичному, так і практичному відношенні. На його думку, зазначене обумовлено тим, що навіть після прийняття Конституції України, яка закріпила досить широкий перелік прав людини і громадянина, державні органи та посадові особи не завжди спроможні належним чином їх реалізувати [3, с. 10].

Належне забезпечення та реалізація прав i законних інтересів кожної особи $є$ вирішальним компонентом становлення і розвитку правової держави, ії головною та кінцевою метою. Право на захист будь-якої особи, яка цього потребує, забезпечується державою, ії компетентними законодавчими, адміністративними та судовими органами. Посилення правового захисту особи, розширення і зміцнення правових гарантій іï прав і свобод в умовах розвитку демократії, а також утвердження незалежної судової влади, як визначального гаранту цих прав і свобод, справедливості і законності $\epsilon$ необхідною умовою функціонування демократичної правової держави.

Висновки. Підбиваючи підсумок, можемо констатувати, що законодавчий захист прав осіб, які постраждали внаслідок кримінального правопорушення підійняв кримінальний процесуальний закон на новий рівень, який нічим не поступається загальновизнаним європейським та світовим стандартам. Та закріплений конституційним положенням про те, що права, свобо- ди та законні інтереси людини, які $є$ найвищою цінністю та їхнє визнання і захист - являється найважливішим обов'язоком держави. Адаптація кримінального процесуального законодавства України до acquis $€ C$ потребує належного наукового супроводу, проведення фундаментальних досліджень з питань, які становлять сутність вищенаведених та інших положень, визначає пріоритетні напрями розвитку законодавчого простору України у забезпеченні прав, свобод та законних інтересів учасників кримінального провадження.

\section{Література}

1. Конституція України. Київ : Паливода, 2017. С. 5.

2. Кримінально-процесуальний кодекс України. Київ : Паливода, 2017. С. 7-8.

3. Аблязов Д.Е. Соціальна, правова держава та права людини і громадянина. Форум права. 2012. № 1. С. 10.

4. Герасимчук О.П. Теоретичні та практичні аспекти професійного захисту потерпілого. Часопис Нац. ун-ту «Острозька академія». Серія «Право». 2011. № 1 (3). C. $1-2$.

5. Маляренко В.Т. Перебудова кримінального процесу України в контексті європейських стандартів : монографія. Київ : Юрінком Інтер, 2005. 388 с.

6. Скакун О.Ф. Теорія права і держави : підручник. Київ : Правова єдність, 2012. 523 с.

7. Блатова Н.Т., Мелков Г.М. Статут Організації 0б'єднаних Націй. Международное право в документах : учеб. пособие / сост.: Н.Т. Блатова, Г.М. Мелков. 3-е изд., перераб. и доп. Москва, 2002. 824 с.

8. Удовенко Г.И. Обеспечение прав человека. Голос Украины. 2003. № 233-234 (3233-3234). 9 декабря. С. 8.

9. World Justice Project (WJP). URL: https:// gtmarket.ru/research/rule-of-law-index/info.

Ребезюк В. М., аспірант кафедри кримінального процесу Національної академії внутрішніх справ 